\title{
Strategies and policies for developing SMEs based on creative economy
}

\author{
Made Kembar Sri Budhi ${ }^{a}$, Ni Putu Nina Eka Lestari ${ }^{b}$, Ni Nyoman Reni Suasih ${ }^{a}$ and Putu Yudy \\ Wijaya $^{c}$
}

${ }^{a}$ Faculty of Economics and Business, Udayana University, Denpasar, Bali, Indonesia

${ }^{b}$ Faculty of Economics and Business, Undiknas University, Denpasar, Bali, Indonesia ${ }^{c}$ Faculty of Economics Business and Tourism, Hindu Indonesia University, Denpasar, Bali, Indonesia

\section{CH R O N I C L E}

\section{Article history:}

Received: January 28, 2020

Received in revised format:

January 302020

Accepted: February 29, 2020

Available online:

March 2, 2020

Keywords:

SMEs

Creative economy

Digital economy

Inclusive economy

\section{Introduction}

Small and Medium Enterprises (SMEs) play an important role for the growth of the economies of the developing countries (Arshad \& Arshad, 2019). SMEs also play an essential role for the national economy of Indonesia. This is evidenced from the number of SMEs as much as 62.9 million units with a unit share reaching 99.99 percent, compared to large businesses totaling 5,460 units with a unit share of 0.01 percent in 2017 (Ministry of Cooperation and SMEs, 2018). SMEs also have a real role as one of the drivers of economic growth in various countries, such as New Zealand, India, Sri Lanka, China, Malaysia (Darroch, 2005; Kumarawadu, 2008; Huang et al., 2009; Kuncoro \& Sriani, 201). Based on 2015 ADB Institute data, it is known that the contribution of SMEs to providing employment opportunities is very high, which is 97.2 percent. The contribution of SMEs to Gross Domestic Income (GDP) is among the highest compared to other countries in Asia, amounting to 57.8 percent (Wilantara \& Susilawati, 2016). On the other hand, SME market share in Indonesia is still largely in the local market. The SME product export value is only able to reach 15 percent, far below the Philippines, Thailand or Malaysia. This is quite reasonable because the market area in the country is still wide, and business actors' understanding of export activities is still limited. Based on the SME composition, the micro business unit provided the largest contribution, reaching 98.7 percent with a contribution to GDP reaching 30.1 percent. This value is lower than the contribution of large businesses totaling 5,460 units to GDP reaching 42.9 percent (Ministry of Cooperation and SMEs, 2018). These conditions indicate that the contribution of SMEs to GDP still has a high opportunity to be increased. This illustration shows the importance of developing SMEs in

* Corresponding author

E-mail address: kacung dobel@yahoo.com (M. K. S. Budhi)

(C) 2020 by the authors; licensee Growing Science, Canada doi: $10.5267 /$ j.msl.2020.3.005 
the Indonesian economic model amidst the trend of economic and financial digitalization. The majority of SMEs are engaged in agriculture, animal husbandry, plantation and fisheries by 49 percent, while the trade in the hotel and restaurant sector by 29 percent. The characteristics of SME business activities are: (1) human resources with relatively low education levels; (2) Product quality is not standardized; (3) simple technology; (4) limited marketing scope in the local market; (5) limited capital (Bank of Indonesia, 2005). Darwin (2018) explained that SMEs which represent the majority of the people have a weak position. Barriers to the development of SMEs in Indonesia can be grouped into two namely external and internal obstacles. External barriers include: (1) limited access to business financing, caused by high cost of funds, and guarantees; (2) high infrastructure costs due to high logistics costs due to poor quality of roads, ports, airports, funding and legal issues; and (3) inefficient bureaucratic services, caused by high levels of corruption, and the ratio of civil servants compared to high population. Internal barriers include: (1) institutional and human resources; (2) marketing and technology; and (3) intellectual capital.

The availability of fast internet services is important in business activities in the era of the industrial revolution 4.0. The availability of fast internet will be able to expand financial inclusion, due to the increasingly open flow of financial digitalization. In this digital era, around 83 percent of consumers are using social media to shapes the perception of business (Dutot \& Bergeron, 2016). Research by Stryjak and Sivakumaran (2019) in the 2019 Mobile Economy report estimates that around 25.2 billion types of goods and 5.8 billion of the world's population will be connected by the internet in 2025 . Connectivity between individuals in the digital world will lead to an expansion of inclusiveness. The presence of a digital economy will facilitate individual activities, one of which is by utilizing the existence of e-commerce. Financial inclusion in Indonesia is determined by the dimensions of accessibility, while the dimensions of availability and have a limited role (Sanjaya \& Nursechafia, 2015). Digital services not only encourage economic growth in Indonesia, but also change business models and replace traditional financing methods. Digital financial services will increase access to the financial system, thus providing benefits to the national economy. According to a world bank study, an increase in inclusive financial system facilities by one percent can increase GDP per capita growth by 0.03 percent. This economic growth will result in increased employment. Increased banking access will have an impact on business development, especially SMEs, which has become easier. New entrepreneurs are now emerging as easy way to sell products through the internet. Traders do not have to have conventional stalls or shops to sell their products. They can sell products using a variety of media, such as social media, applications.

Rapidly developing technology has changed the way people shop for transactions by conducting electronic commerce transactions (e-commerce). At first the trade takes place offline, where the seller and buyer meet directly. The value of Indonesia's electronic transactions (e-commerce) in 2015 reached US \$ 3.5 billion, up 250 percent compared to 2011. Based on Google and Temasek research in its 2018 e-Conomy SEA report, the Gross Merchandise Value (GMV) of the e-industry commerce for Indonesia of US \$ 12.2 billion, beating Malaysia, Philippines, Singapore, Thailand and Vietnam (Eka, 2018).

Based on World Bank data obtained from the Global Financial Index Release in 2018 it is known that the value of Indonesia's banked population has only reached 49 percent of the total adult population in 2017. The Government in the National Financial Inclusive Strategy (SNKI) targets banked people at 70 percent in 2019. The Ministry of Cooperatives and SMEs launched 3.79 million SMEs already utilizing online platforms in marketing their products. This number is around $8 \%$ of the total SMEs in Indonesia (Ministry of Communication and Information, 2017). The number is very small compared to the number of SME units in Indonesia, and the potential of Indonesia's digital economy is supported by a high productive population. This condition indicates that there are still gaps in financial access and digitalization among SMEs.

The innovation and spirit of firms, generation of wealth in an economy, and availability of job opportunities greatly depend on small-scale firms and businesses (Almansour et al., 2020). Creative industries have an important role in developing national and regional economies, so they need to be developed in Indonesia (Ministry of Trade, 2008). Important roles include: (1) making significant economic contributions such as increasing employment, increasing exports, and contributing to GDP; (2) creating a positive business climate that impacts other sectors; (3) building the nation's image and identity such as tourism, national icons, building cultural heritage, and local values; (4) based on renewable resources such as science and creativity enhancement; (5) creating innovation and creativity which are competitive advantages of a nation; and (6) can provide positive social impacts such as improving the quality of life and social tolerance (Darwanto, 2013).

Based on the results of the 2016 creative economy survey, it is known that the creative economy is able to contribute significantly to national economic growth. In 2015, this sector contributed 852 trillion rupiah to the national GDP (7.38\%), absorbed 15.9 million workers (13.90\%), and export value of US \$ 19.4 billion (12.88\%). The data also shows a significant increase in the contribution of the Creative Economy to the national economy from 2010-2015 at 10.14\% per year (Creative Economic Agency, 2017a). This proves that the Creative Economy has the potential to develop in the future. In addition, the creative economy also opens up opportunities for human capital development that arise due to disruption of economic and financial digitalization.

\section{The research objective}

The purpose of this study is 1) to develop a strategy for strengthening and developing SMEs based on a creative economy that is sustainable and inclusive in the era of the industrial revolution 4.0 in Indonesia, particularly in the Province of Bali. 2) To provide strategic input based on the experience of SMEs in the Province of Bali in order to encourage the competitiveness of 
SME exports. 3) To map the hierarchy policy of developing a creative economy-based SME business model in the era of the industrial revolution 4.0 in Indonesia, especially in the Province of Bali.

\section{Literature Review}

\subsection{Small and Medium Enterprises (SMEs)}

Small and Medium Enterprises (SMEs) in Indonesia are regulated based on Law Number 20 Year 2008, in Law Number 20 of 2008, SMEs are described as: "a small company owned and managed by someone or owned by a small group of people with a certain amount of wealth and income."

\subsection{Creative Economy}

New ideas about product, service, organizational structure or technology are the change that could be new to the organization and new to the world i.e. radical innovation (Najma \& Raziq, 2019). Creative economy is a new economic concept that relies on ideas, ideas, or creativity from human resources (HR) as the main production factor in its economic activities. The main resource in a creative economy is creativity, namely the capacity or ability to produce or create something unique, a solution of a problem, or something different from the standard (thinking outside the box). The creative economy is believed to be able to become the latest economic axis in Indonesia in the future. The economic model tends not to require subsidies or massive investment from the government (weightless), but it has a big impact on the economy, and at the same time can be a new economic motor. SMEs seem to rely more on the development of their internal practices to support innovation (Wijaya et al., 2019). The UNCTAD (United Nations Conference on Trade and Development) report in (Creative Economic Agency, 2017b) shows a trend in which the creative economy contributes greatly to increasing added value, creating jobs, and also exports in various countries, including Indonesia. Technological developments, especially the digital revolution, have made the creative industry one of the most profitable and dynamic sectors. In the Statistical Data Book and Creative Economy Survey Results (Creative Economic Agency, 2017a) it is mentioned that Ernst and Young (2015) mapped the global creative economy for the first time in the world and found that the Creative and Cultural Industries (Cultural and Creative Industries or CCI) is worth 2.3 trillion US dollars (US \$ 2.3 trillion or 30,654 trillion rupiah). This is surprising because CCI is a non-traditional economic model that is relatively new, but has tremendous potential. In the traditional economic system, traded goods have tangible and standardized or measurable exchange rates, for example oil or other commodities. Creative economy has no intangible and objective alias non-standardized exchange rates.

\subsection{Inclusive Economic Growth}

Growth is an important prerequisite for creating inclusive growth. Klasen (Asian Development Bank, 2010) states that it is important to determine what economic episodes have characteristics as inclusive growth. According to Amalina et al. (2013), there are two possibilities for this, the first seeing through the process, and the second is seeing through the results. The first focus places inclusive economic growth on expanding growth between sectors or labor-intensive so that inclusive growth can be said as growth that involves the participation of all parties without discrimination and is able to involve all economic sectors. The second focus is on the results of the growth process. In this case, inclusive growth is seen as closely related to the concept of pro-poor growth. In other words, based on the results achieved, inclusive growth is growth that is able to reduce the "disadvantaged" groups in the economy. Based on these two focuses, inclusive growth can be defined as growth that does not discriminate and is able to ensure equitable access to growth as well as growth that can reduce groups that do not benefit from growth (reducing disparity between groups) (Hapsari et al., 2013).

\subsection{Digital Economy}

The digital technology enables to create business model innovation (Schwertner, 2017). A digital economy is an economy based on electronic goods and services produced by electronic businesses and traded through electronic commerce. That is, businesses with electronic production and management processes and who interact with partners and customers and carry out transactions through the internet and web technology. Adhikara (2005) explains that an economic system that is moving towards the use of technology in all fields and easy access to information that is increasingly transparent is often referred to as the new economy or termed the digital economy, digital economy, internet economy) or web economy. This indicates that there has been a change. Global changes that have far-reaching effects. In companies, in consumers, in regulations, in technology, even in the economy of each country. To be able to survive, companies must understand the changes that occur. And that understanding must be done in an increasingly short time. In production, companies must look for more efficient ways to produce their products/services. In terms of strategy, companies must formulate precisely who their competitors really are, with whom they must collaborate, how to take advantage of changes that occur, use of new channels, improve competitive advantage, and turn their weaknesses into strengths (Adhikara, 2005). Digital economic and financial opportunities, including fostering innovation, entrepreneurship and economic growth, expanding greater access especially to financial inclusion and SMEs, digital identity that can improve social and public services to be better, and affordable. The presence of new technology expands opportunities to provide services that are more affordable, faster and better (Putra, 2018). 
Bali Province is one of the centers of SMEs based on the creative economy (especially in the handicraft sector). Moreover, Bali is a world tourist destination, so various creative economy-based SME products are very important to support the tourism sector. There are many varieties of products from SMEs in Bali, including snacks, drinks, beauty products, spa products, Balinese gloves, handicrafts, and weaving. All products are of interest to national and global markets

\section{Method}

\subsection{Data}

This research was conducted from the beginning of July to the end of August 2019, located in the Province of Bali, with the object of research focused on Small and Medium Enterprises (SMEs) fostered by Bank Indonesia Representatives of the Province of Bali in 2019. The data in this study consisted of primary data and secondary data. Primary data is obtained directly from relevant stakeholders and SME actors, while secondary data is obtained from related documents. The method of data collection is done through documentation techniques, focus group discussions (FGD), and interviews with SMEs representing business people, academics, researchers, and elements of relevant government agencies.

\subsection{Data Analysis Techniques}

Qualitative data analysis takes place during the data collection process rather than after completion of data collection (Sugiyono, 2016). Data analysis techniques used in qualitative research are carried out through three stages, namely data reduction, data presentation, and data verification (Miles and Huberman, 1992).

\subsection{SWOT Analysis}

Data and information collected from the Focus Group Discussion (FGD) were analyzed using SWOT analysis, identifying strategic factors to formulate the strategy.

\subsection{MULTIPOL Analysis}

To analyze and compile the hierarchy policy prospective analysis techniques using the MULTI-criteria and POLicy (MULTIPOL) are used. Three main elements in MULTIPOL analysis are scenario, policy (direction of policy), action (Fauzi, 2019). Potential pathways for policies that can be formulated through MULTIPOL analysis are shown in Fig. 1 below.

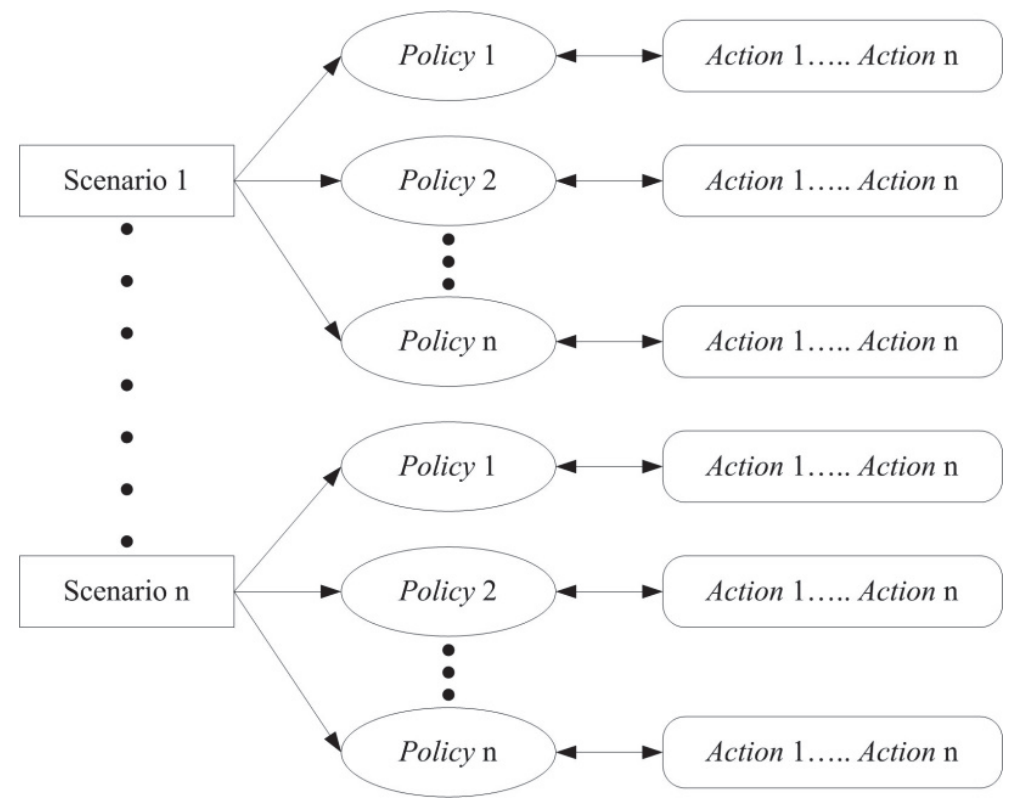

Fig. 1. Policy Potential Path/Policy Framework (Fauzi, 2019)

\section{Result and discussion}

\subsection{SWOT analysis}

Based on the calculation of the strategic factor indicator value intervals, it can be seen the results criteria as in Table 1. 
Table 1

Criteria for Analysis Results

\begin{tabular}{ccccc}
\hline Value & Range of Value & Criteria & Internal & External \\
\hline 4 & $3,26-4,00$ & Very good & Strength & Opportunity \\
3 & $2,51-3,25$ & Good & Strength & Opportunity \\
2 & $1,76-2,50$ & Less & Weakness & Threat \\
1 & $1,00-1,75$ & Very less & Weakness & Threat \\
\hline
\end{tabular}

\subsubsection{Identification of Strategic Factors for Development of SMEs}

The results of focus group discussions can be identified strategic factors that determine the success of SMEs consisting of internal and external strategic factors, as shown in Table 2.

Table 2

Internal and External Strategic Factors that Determine SME Development

\begin{tabular}{|c|c|c|c|}
\hline No & Internal Strategic Factors & No & External Strategic Factors \\
\hline 1. & Business capital owned & 1. & Easiness of business licensing process \\
\hline 2. & Business relationships/networks & 2. & Low business permit fees \\
\hline 3. & Quality and competence of human resources & 3. & Business empowerment policies by the government \\
\hline 4. & Utilization of Technology and equipment & 4. & Regular guidance from stakeholders and the government \\
\hline 5. & Adequate product promotion & 5. & Business location and strategic supporting facilities \\
\hline 6. & Online marketing and social media & 6. & $\begin{array}{l}\text { Easiness of assistance of facilities and equipment from the gov- } \\
\text { ernment and NGOs }\end{array}$ \\
\hline 7. & $\begin{array}{l}\text { Access to extensive information related to production fac- } \\
\text { tors, and market conditions }\end{array}$ & 7. & Easiness procedure and availability of business credit \\
\hline 8. & An adequate financial statement accounting system & & \\
\hline 9. & Product innovation & & \\
\hline 10. & Brand excellence and product packaging & & \\
\hline 11. & Easiness of raw materials & & \\
\hline
\end{tabular}

\subsection{Formulation of SME Development Policy and Strategy}

Based on IFAS weighted average values in Table 3, it appears that internal strategic factors, SMEs in Bali Province are currently valued at 3.51 , which means above 2.5 which is the strength of SMEs. All internal strategic variables have values ranging from 0.19 to 0.42 . Quality and competency factors in human resources have the lowest weight value, which is 0.19 . These conditions indicate that the quality and competence of human resources are still inadequate in improving the performance of SMEs. This is due to the fact that most of the SMEs in Bali Province are micro and small businesses, so they have limited resources. SMEs are more optimizing the human resources they have to work on various lines of work with the aim of production efficiency. SMEs have difficulty obtaining quality human resources with limited resources, and have an ethical fear that good quality human resources will easily move to other businesses. The factor of brand excellence and product packaging is an important factor to improve the performance of SMEs, because it has the highest value of 0.42 . This is due to the condition of the industry in the revolutionary era 4.0 creativity is needed in producing products, because the types of products produced are relatively homogeneous.

Table 3

Internal Factor Analysis Summary (IFAS) of SMEs in Bali Province

\begin{tabular}{|c|c|c|c|c|c|}
\hline No. & Internal Factor Indicators & Sum & Weight (\%) & Rating & Weight Value \\
\hline 1. & Business capital owned & 36 & 0.09 & 3.6 & 0.34 \\
\hline 2. & Business relationships/networks & 36 & 0.09 & 3.6 & 0.34 \\
\hline 3. & Quality and competence of human resources & 27 & 0.07 & 2.7 & 0.19 \\
\hline 4. & Utilization of technology and equipment & 36 & 0.09 & 3.6 & 0.34 \\
\hline 5. & Adequate product promotion & 38 & 0.10 & 3.8 & 0.38 \\
\hline 6. & Online marketing and social media & 36 & 0.09 & 3.6 & 0.34 \\
\hline 7. & $\begin{array}{l}\text { Access to extensive information related to production factors, and market } \\
\text { conditions }\end{array}$ & 37 & 0.10 & 3.7 & 0.36 \\
\hline 8. & An adequate financial statement accounting system & 31 & 0.08 & 3.1 & 0.25 \\
\hline 9. & Product innovation & 36 & 0.09 & 3.6 & 0.34 \\
\hline 10. & Brand excellence and product packaging & 40 & 0.10 & 4 & 0.42 \\
\hline 11. & Easiness of raw materials & 29 & 0.08 & 2.9 & 0.22 \\
\hline Total & & 382 & 1.00 & & 3.51 \\
\hline
\end{tabular}

Based on the summary of the External Factor Analysis Summary (IFAS) of SMEs in Bali Province, as shown in Table 3 it is known that the weighted value of the current external strategic variable is 3.59 , which means it has an opportunity to be developed, because the value is greater than 2.50. The routine coaching factor from stakeholders and the government has the lowest value, which is 0.23 . These conditions indicate that the ability of the government and stakeholders in conducting guidance to SMEs is still limited, both from the budget, the amount, and based on certain business fields 
Table 4

External Factor Analysis Summary (EFAS) of SMEs in Bali Province

\begin{tabular}{|c|c|c|c|c|c|}
\hline No. & External Factor Indicators & Sum & Weight $(\%)$ & Rating & Weight Value \\
\hline 1. & Easiness of business licensing process & 38 & 0.15 & 3.8 & 0.58 \\
\hline 2. & Low business permit fees & 37 & 0.15 & 3.7 & 0.55 \\
\hline 3. & Business empowerment policies by the government & 36 & 0.15 & 3.6 & 0.52 \\
\hline 4. & Regular guidance from stakeholders and the government & 24 & 0.10 & 2.4 & 0.23 \\
\hline 5. & Business location and strategic supporting facilities & 38 & 0.15 & 3.8 & 0.58 \\
\hline 6. & Easiness of assistance of facilities and equipment from the government and NGOs & 37 & 0.15 & 3.7 & 0.55 \\
\hline 7. & Easiness procedure and availability of business credit & 37 & 0.15 & 3.7 & 0.55 \\
\hline \multicolumn{2}{|r|}{ Total } & 247 & 1.00 & & 3.59 \\
\hline
\end{tabular}

\subsection{Strategic Positioning and Formulation}

Based on internal and external analysis, it is known that the IFAS weighted average value of UKM in Bali Province is 3.51 and EFAS weighted average value is 3.59 and its position in IE Matrix is in Cell I (see Fig. 1) which means that UKM in the Province of Bali has strong category competitiveness and high category attractiveness, so that the strategic position of SMEs in the Province of Bali is in the condition of Growth and Build (David, 2006), as shown in Fig. 2.

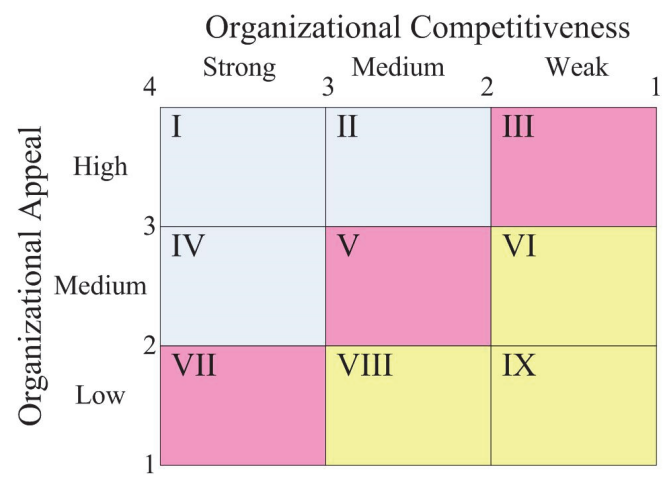

Fig. 2 Strategic Position of SMEs in the Province of Bali

\subsection{Determination of SMEs Developing Strategies in Bali Province}

The strategic position of SMEs in Bali Province is in the Growth and Built position in cell I, so the strategy adopted is intensive strategy (market penetration, market development and product development) or integration (backward integration, forward integration and horizontal integration) (David, 2006). The appropriate intensive strategies implemented by SMEs in the Province of Bali are (1) Market penetration strategy, which is a strategy of finding a wider market share for existing products through a more active marketing effort. (2) Product development strategy, which is a strategy that seeks to increase revenue by improving existing products or developing new products. The market penetration strategy for SMEs can be done with a work program in the form of opening a wider market share both local and export. The development of the internet encourages customers to obtain information easily and quickly, so that consumers faced by SMEs are sensitive to price and quality. SMEs need to promote their products online by utilizing internet media and applications. Open market segments for SME products from the age, culture, or other types of segments.

In the market penetration strategy, SMEs should segment the market, determine the target market, determine the market position, diversify the market. Marketing mix of products by adding digital processes; in places with new distribution models and representations; on prices with price transparency and new pricing models; promoting off line and on line; carry out internal and external optimization processes; conduct physical evidence online and integration (Septyato \& Dewanto, 2016). Implementation of the product development strategy in SMEs is by creating new products both in terms of size, shape, new product lines. Diversifying products by innovating processes and products. In relation to the growth and built of SMEs, especially the creative industries in the Province of Bali, the development roadmap that can be carried out is to direct the pattern of development in the Province of Bali with a one island management system, followed by strengthening competencies, and implementing development.

\subsection{MULTIPOL analysis}

The results of the MULTIPOL analysis based on the scores for each policy and the mean score, as well as the standard deviations obtained, can be shown in Table 5. The higher the position number, the better the action performance 
Table 5

Evaluation Based on Action and Policy

\begin{tabular}{|c|c|c|c|c|c|c|c|}
\hline \multirow[b]{2}{*}{ Actions } & \multicolumn{4}{|c|}{ Policy } & \multirow[b]{2}{*}{ Mean } & \multirow{2}{*}{$\begin{array}{l}\text { Standard } \\
\text { Deviation }\end{array}$} & \multirow[b]{2}{*}{ Number } \\
\hline & Capital Policy & $\begin{array}{l}\text { Infra-structure } \\
\text { policy }\end{array}$ & Technology Policy & $\begin{array}{c}\text { Marketing } \\
\text { Policy }\end{array}$ & & & \\
\hline Capital facilitation & 14.6 & 13.4 & 14.2 & 14 & 14.1 & 0.4 & 3 \\
\hline Industry and trade cluster & 9.8 & 10.2 & 9.6 & 10 & 9.9 & 0.2 & 1 \\
\hline Product innovation & 15.2 & 14.4 & 15.2 & 14.8 & 14.9 & 0.3 & 4 \\
\hline E-commerce services & 14.5 & 15.1 & 15.8 & 14.8 & 15.1 & 0.5 & 5 \\
\hline Institutional relations & 10.2 & 11.4 & 11.2 & 10.8 & 10.9 & 0.4 & 2 \\
\hline Promotion/exhibition facilitation & 15.5 & 14.9 & 15.7 & 15.2 & 15.4 & 0.3 & 6 \\
\hline Export facilitation & 14.9 & 15.5 & 16 & 15.2 & 15.4 & 0.4 & 7 \\
\hline
\end{tabular}

Fig. 3. below presents the results of MULTIPOL in the form of closeness map or closeness between programs (actions) and policies (policy).

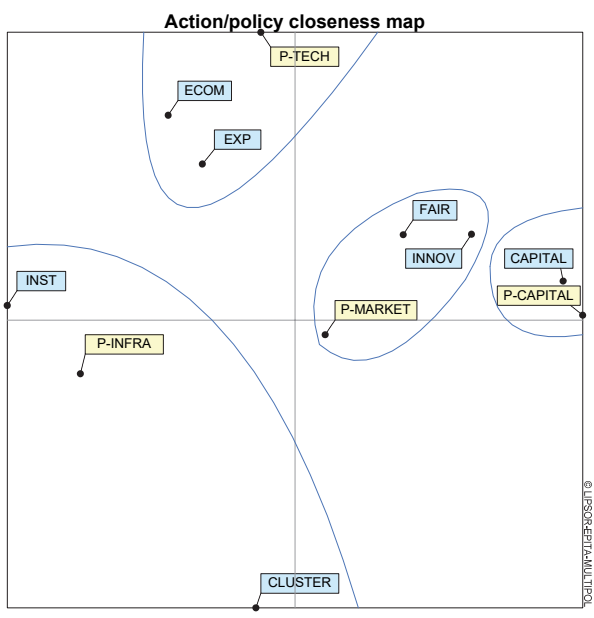

Fig. 3 Linkages between Policy and Action (Closeness Map)

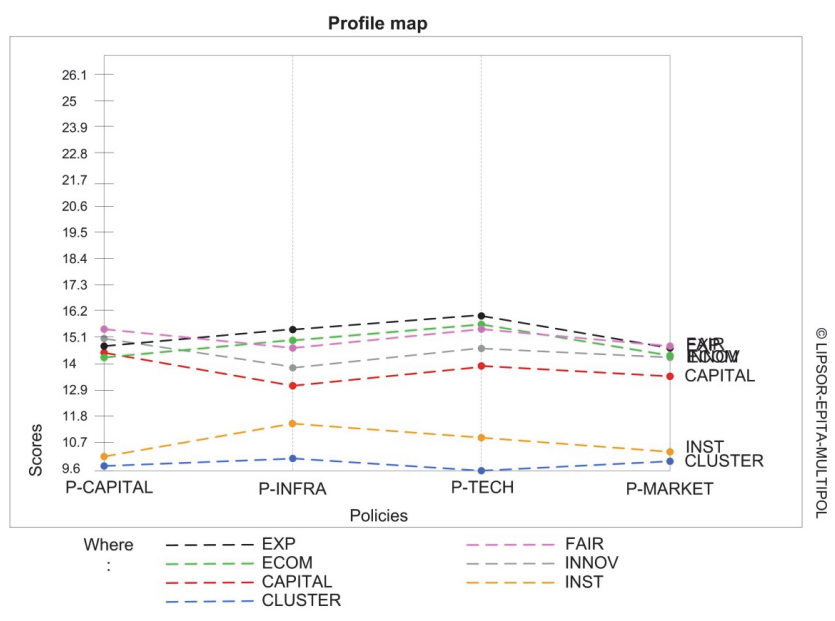

Fig. 4. Profile Map of SMEs Developing

Based on Fig. 3 it is found that e-commerce facilitation and export facilitation programs are closer to technology policy. Closer infrastructure policy is an institutional strengthening program and industrial cluster development. The capital policy is certainly close to the capital facilitation program. Finally, marketing policies that are close to innovation and promotion programs or product exhibition facilitation. MULTIPOL analysis also produces a profile map that links scores for each program (actions) with policies (policy). As shown in Fig. 4, export facilitation programs are superior in three types of policies, namely infrastructure policy, technology policy, and marketing policy (together with marketing/exhibition facilitation programs). While for capital policy, the marketing/exhibition facilitation program received the highest score. Table 6 and Fig. 5 present the score of each policy against the scenario. From the results, it appears that the superior technology policy in the SME fostered scenario, while the capital policy has the highest value in the independent SME scenario. If seen from the average value of the two scenarios, the best position is obtained in technology policy, then followed by capital policy and marketing policy

Table 6

Score of Policy Against Scenario

\begin{tabular}{|c|c|c|c|c|c|}
\hline \multirow{2}{*}{ Policy } & \multicolumn{2}{|c|}{ Scenario } & \multirow{2}{*}{ Mean } & \multirow{2}{*}{ Standard Deviation } & \multirow{2}{*}{ Rank } \\
\hline & Coached SMEs & Self-sustained SMEs & & & \\
\hline Capital policy & 36 & 38 & 37.1 & 1 & 3 \\
\hline Infrastructure policy & 36 & 34 & 34.9 & 1 & 1 \\
\hline Technology policy & 38 & 37 & 37.5 & 0.5 & 4 \\
\hline Marketing policy & 36 & 36 & 36 & 0 & 2 \\
\hline
\end{tabular}

The overall results of the MULTIPOL analysis can be presented in the form of a potential policy path. Fig. 5 presents the potential policy paths that can be taken through various programs (actions) that are in accordance with the policies. The digital transformation is required by incumbent to develop innovation on product and service business model based on customer experience orientation (Mihardjo et al., 2019). An SME's decision to participate in a social media platform is strategic (Imran and Jian, 2018). This decision can be SME's self-protective response to dynamic business environment, which aligning the business resources and activities to sustain competitive advantage which leads to higher firm performance (Eisenhardt and Martin, 2000; Teece, 2007). Technology policy both in the scenario of fostered SMEs and independent SMEs through ecommerce service development programs and export facilitation. Thus, only the capital policy is also good for both scenarios 
through a capital facilitation program. Including marketing policies through product innovation programs and conducting promotions through exhibitions as well in the scenario of fostered and independent SMEs. A distinct policy is an infrastructure policy that is only suitable for the SME-guided scenario, with infrastructure development programs and industrial clusters. In small and medium enterprises and in big firms, they all use of either debt or equity or both (Berger \& Udell, 1998).

These results indicate that when scenarios are directed at fostered SMEs, more policies are needed, whereas for SMEs that are already capable of being independent, the policies required are not as complex as the guided SMEs. Therefore, policies and programs need to be adjusted to the conditions of SMEs (scenarios), and in the future SMEs need to be directed to become independent SMEs.

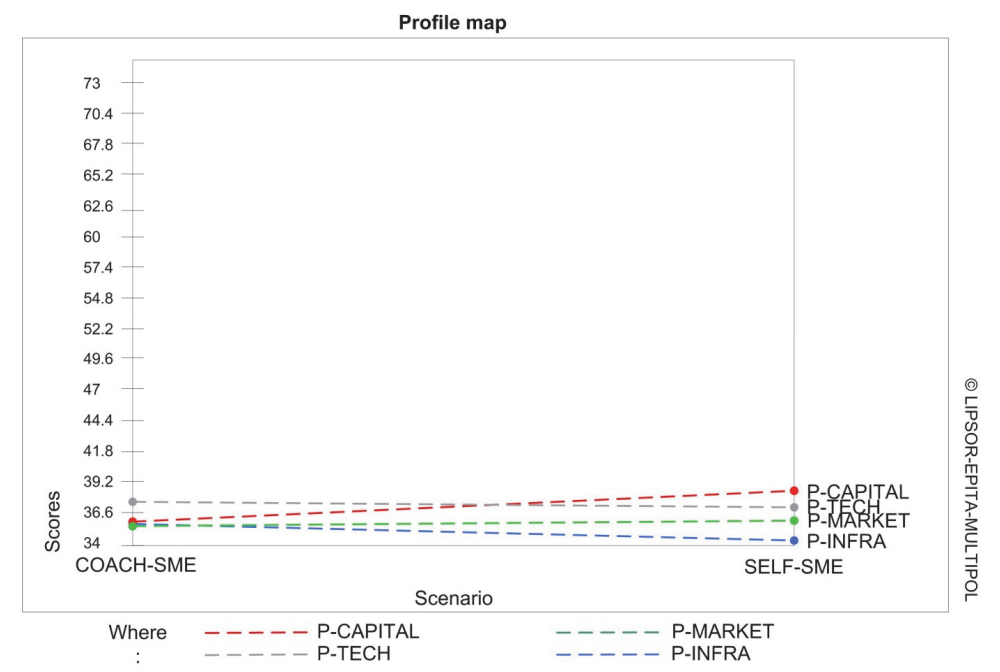

Fig 5. Profile Map for Policy Against Scenario

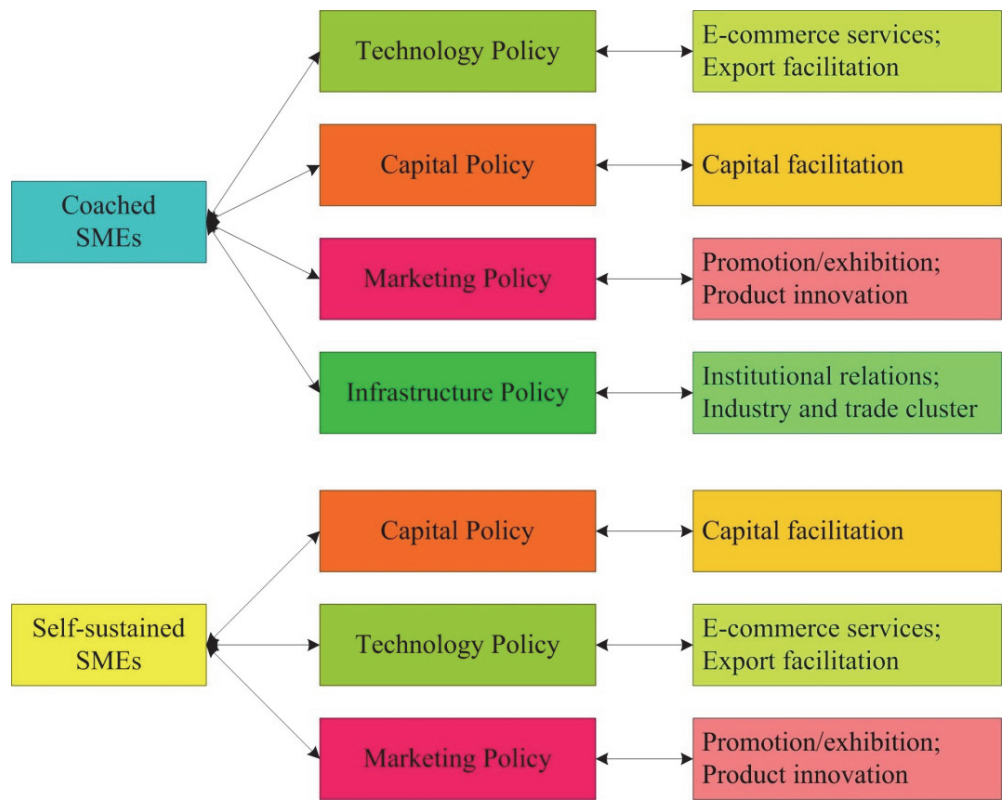

\section{Conclusions}

Fig 6. Potency of Policy Path and Program

The ability of creative economy-based SMEs to compete in the global era depends on 1) internal factors such as: venture capital, business relationships / networks, quality and competence of human resources, use of technology and equipment, product promotion, online marketing, access to information, accounting systems, product innovation, brand, and ease of raw materials. 2) external factors, namely: licensing processes and costs, empowerment policies, coaching by stakeholders, business location, facility assistance, and business credit. SBM in Bali Province is in a position of growth and built, so the strategy adopted is intensive strategy (market penetration, market development and product development) or integration (backward 
integration, forward integration and horizontal integration). Development policies for SMEs, especially in the era of the industrial revolution 4.0, need to be directed so that the guided SMEs become independent SMEs. The policy package for the development of target SMEs includes technology, capital, marketing and infrastructure policies. As for the development of more independent SMEs, the policy is more focused on capital, technology and marketing policies.

\section{References}

Adhikara, C.T. (2005). Siapa Konsumen Kita? Analisis Perubahan Konsumen di Era "Ekonomi Baru”. Jurnal The Winners. 6(2), 176-183.

Almansour, A., Alrawashdeh, N., \& Almansour, B. (2019). The impact of capital structure on the performance of microfinance institutions. Management Science Letters, 10(4), 881-888.

Hapsari, S. A. D., Hutagaol, M. P., \& Asmara, A. (2013). Pertumbuhan Inklusif: Fenomena Pertumbuhan Inklusif di Kawasan Indonesia Bagian Barat dan Indonesia Bagian Timur. Jurnal Ekonomi dan Kebijakan Pembangunan, 2(2), 85-112.

Arshad, M., \& Arshad, D. (2019). Internal capabilities and SMEs performance: A case of textile industry in Pakistan. Management Science Letters, 9(4), 621-628.

Asian Development Bank. (2010). Key Indicators for Asia and the Pacific. Asian Development Bank: Mandaluyong City, Philippines.

Bank of Indonesia. (2015). Profil Bisnis Usaha Mikro Kecil dan Menengah (UKM). Jakarta: Bank Indonesia bekerjasama dengan Lembaga Pengembangan Perbankan Indonesia (LPPI).

Bank of Indonesia. (2005). Data Statistik dan Hasil Survei. Jakarta: Bank Indonesia.

Berger, A., \& F Udell, G. (1998). The economics of small business finance: The roles of private equity and debt markets in the financial growth cycle. Journal of Banking \& Finance, 22(6), 613-673.

Creative Economic Agency. (2017). Data Statistik dan Hasil Survei Ekonomi Kreatif. Jakarta: Creative Economic Agency cooperated with Central Bureau of Statistics.

Creative Economic Agency. (2017). OPUS Outlook Ekonomi Kreatif 2017. Jakarta: Creative Economic Agency.

Darwanto, D.D.T.U. (2013). Pengembangan Usaha Mikro, Kecil, dan Menengah (UKM) Berbasis Ekonomi Kreatif di Kota Semarang. Diponegoro Journal of Economics, 2(4), 1-13.

Darroch, J. (2005). Knowledge Management, Innovation and Firm Performance. Journal of Knowledge Management, 9(3), $101-115$.

Darwin. (2018). UKM Dalam Perspektif Pembiayaan Inklusif di Indonesia. Jurnal Ekonoi dan Pembangunan, $26(1), 59-75$.

David, F. R. (2006). Strategic Management, Concepts and Cases. Pearson Prentice Hall.

Dutot, V., \& Bergeron, F. (2016). From strategic orientation to social media orientation: Improving SMEs' performance on social media. Journal of Small Business and Enterprise Development, 23(4), 1165-1190.

Ministry of Trade of Republic of Indonesia. (2008) Pengembangan Ekonomi Kreatif Indonesia 2015. Jakarta: Ministry of Trade of Republic of Indonesia.

Eka, R. (2018). Riset Google-Temasek: Indonesia Kuasai Pangda Pasar Ekonomi Internet di Asia Tenggara. www.dailysocial.id.

Eisenhardt, K. M., \& Martin, J. A. (2000). Dynamic capabilities: what are they? Strategic Management Journal, 21(10-11), 1105-1121.

Huang, J.W. \& Li, Y.H. (2009). The Mediating Effect of Knowledge Management on Social Interaction and Innovation Performance. International Journal of Manpower, 30(3), 285-301.

Imran, M., \& Jian, Z. (2018). Social media orientation and SME export performance: A conceptual framework. International Journal of Management. Accounting and Economics, 5(6), 473-481.

Mihardjo, L., Sasmoko, S., Alamsjah, F., \& Elidjen, E. (2019). Digital leadership role in developing business model innovation and customer experience orientation in industry 4.0. Management Science Letters, 9(11), 1749-1762.

Ministry of Communication and Information of Republic of Indonesia. (2017). Kemenkop UKM: 3,79 Juta UKM Sudah Go Online. www.kominfo.go.id.Putra, N.E. 2018. Perkembangan Ekonomi Digital di Indonesia dari Segi Tren, Peluang, dan Tantangan. Available: http://www.feb.ui.ac.id/blog/2018/11/23/perkembangan-ekonomi-digital-di-indonesia-dari-segitren-peluang-dan-tantangan/

Kumarawadu, P. (2008). Achieving Competitive Advantage through Knowledge Management Initiatives in Small and Medium Software Industry. Journal of Information \& Knowledge Management, 7(4), 255-265.

Kuncoro, W. \& Suriani, W.O. (2017). Achieving sustainable competitive advantage through product innovation and market driving. Asia Pacific Management Review, 23(3), 186-192.

Miles, B.M. \& Huberman, M. (1992). Analisis data Kualitatif Buku Sumber Tentang Metode-metode Baru. Jakarta: UIP.

Najma, H., \& Raziq, A. (2019). Effects of knowledge management practices on innovation in SMEs. Management Science Letters, 9(2019), 997-1008.

Sanjaya, I. M., \& Nursechafia. (2015). Inklusi Keuangan dan Pertumbuhan Inklusif: Analisis Antar Provinsi di Indonesia. Buletin Ekonomi Moneter dan Perbankan, 18(3), 281-306.

Schwertner, K. (2017). Digital transformation of business models. Trakia Journal of Science, 15(1), 388-393.

Septyato, D. \& Dewanto, I.J. (2016). Pengembangan Strategi E-Marketing UKM di Indonesia. Prosiding Seminar Nasional Dinamika Global: Rebranding Keunggulan Kompetitif Berbasis Kearifan Lokal. ISBN-978-602-60569-2-4 Jember FEB UNEJ 17 Desember. 
Stryjak, J. \& Sivakumaran, M. (2019). The Mobile Economy 2019. GSM Association.

Sugiyono. (2016). Metode Penelitian Kuantitatif, Kualitatif dan $R \&$ D. Bandung: Alfabeta.

Teece, D. J. (2007). Explicating dynamic capabilities: the nature and microfoundations of (sustainable) enterprise performance. Strategic management journal, 28(13), 1319-1350.

Wijaya, P.Y., Rahyuda, I K., Yasa, N.N.K., \& Sukaatmadja, I P.G. (2019). Dilemma of innovation in silver craft SMEs in Gianyar Regency of Bali Province, Indonesia. Revista Espacios, 40(22), 15-22.

Wilantara, R.F. \& Susilawati. (2016). Strategi dan Kebijakan Pengembangan UKM Upaya Meningkatkan Daya Saing UKM Nasional di Era MEA. Cetakan Pertama. Bandung: Refika Aditama.

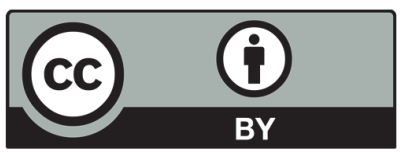

(C) 2020 by the authors; licensee Growing Science, Canada. This is an open access article distributed under the terms and conditions of the Creative Commons Attribution (CC-BY) license (http://creativecommons.org/licenses/by/4.0/). 